\title{
LA INUNDACIÓN
}

Pablo Recal

\section{a todos nosotros}

Palpo la ciudad

porque necesito buscarla

Un hedor come

las sombras que dejaron

las furiosas aguas

Los árboles heridos

desparraman sus ramas

Los edificios ciegos

devuelven sus miradas

Las casas ausentes, quietas

o quizás calladas ...

Mil historias se urden

en cada manzana

Un hombre salvó al vecino

y el amigo recogió seis desconocidos

que durmieron en su almohada

En todas partes

la gente enmudecida lloraba

Un grito de angustia se ahogaba

en sus gargantas

Desesperados, preguntan por los suyos, un hijo, el nieto, su mujer

o su hermana
En los ríos que formaron

esas rabiosas lágrimas

naufragaron siluetas,

recuerdos y esperanzas

Por un momento bajo los brazos, pero los levanto

porque ellos los alzan

Son jóvenes que brotan

de repente

que se toman de las manos

para enhebrar una cadena

de confianza

Veo todo esto

en esta tierra exhausta

y pienso que esos gestos solidarios

conmueven y acompañan

Y me pregunto,

dónde están los que no estaban?

Hoy lunes

una pareja se besa

en la ciudad desolada.

(c) Đ\&९ $\begin{aligned} & \text { Esta obra está bajo una licencia } \\ & \text { de Creative Commons }\end{aligned}$
Reconocimiento-NoComercial-SinObraDerivada
$\underline{4.0 \text { Internacional }}$

\footnotetext{
${ }^{1}$ Poeta independiente. Argentina. Correo electrónico: recapablo@yahoo.com.ar Recepción: 15/7/2020 Aceptación: 13/8/2020
} 